Доц. др Маја Радонић

Факултет за културу и медије

Београд

majar@yandex.ru

821.163.41.09-32 Андрић И. https://doi.org/10.18485/ai_andric.2018.ch10

\title{
АЛИЈА ЂЕРЗЕЛЕЗ, НАШ САВРЕМЕНИК
}

У једној од својих најзначајнијих приповедака „Пут Алије Ђерзелеза“, Иво Андрић је кроз демитологизацију и пародијски поступак, реактуализовао лик типичног јунака епских песама, стварајући тако модерног јунака, човека издвојеног из заједнице, усамљеног и раздираног унутрашњим сукобима и страховима. Рад указује на иронију, пародију и дијалогизацију као основни приповедачки поступак којим је аутор разорио првобитну митску основу приче, да би је реактуализацијом оживео, стварајући слику тескобне егзистенције модерног субјекта, човека који се лелуја између митске представе о својој свемоћи и стварности која неумољиво и доследно разара ту слику.

Къучне речи: Иво Андрић, „Пут Алије Ђерзелеза“, пародија, дијалогизација, мит, реактуализација.

О Андрићевој првој великој приповеци „Пут Алије Ђерзелеза“ из 1920. године често је било говора у нашој књижевно-критичкој и теоријској мисли, а овај рад жели да укаже на неколике аспекте знамените приповетке, који из специфичног угла расветљавају њеног главног јунака, као и на стилски поступак којим писац остварује суштинску модерност свог приповедачког поступка. Пародијски поступак којим Андрић демитологизује славног епског јунака, представља заправо доминантни поступак модерне књижевности прве по- 
ловине 20. века, по моделу који је у својим радовима поставио и расветлио утицајни руски филозоф, теоретичар књижевности и семиолог Михаил Бахтин (18951975), уводећи у теорију књижевности појмове дијалогизације, карневализације, гротеске и полифоније. ${ }^{1}$ Треба напоменути да се Бахтин бавио првенствено романом, али поступци карневализације и дијалогизације као специфичног поетског поступка и предуслова пародирања, присутни су и у Андрићевој првој приповеци, што ће додатно потврдити чињеницу да су се његов велики приповедачки дар, као и суштинска модерност приповедачког поступка, појавили у пуној мери већ у првом значајнијем прозном тексту.

Појам дијалогизације у књижевности, како га је Бахтин дефинисао, представља сучељавање, конфронтацију две позиције, два различита гласа унутар једног прозног текста, а они се остварују процесом пародирања. Да би се дијалогизација ових гласова остварила мора постојати почетна заједничка позиција коју аутор сучељава са различитом позицијом пародирањем и она се може остварити на три начина: између ауторског гласа и гласа протагонисте, између гласа протагонисте и других јунака или између језика текста и неког другог релевентног текста на који овај упућује. ${ }^{2}$ Тако у приповеци „Пут

1 Бахтин 1929. године објављује студију Проблеми стивара-

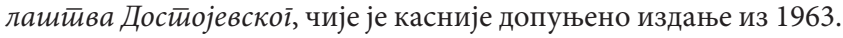
названо Проблеми йоейике Досйојевскої. Већ у првом издању Бахтин уводи појмове дијалогизације и полифоније, да би у студији Франсоа Рабле и нарояна кулитура среgюеі века и ренесансе (1965), кроз анализу ренесансног друштва и културе, дао свеобухватно тумачење карневала и гротеске тј. їротиескної реализма којег он уводи као нови појам.

2 Текст је дијалошки у случају да је дефинисан односом према другим текстовима, или како Бахтин наводи: „аутентична средина исказа у којој он живи и обликује се, јесте дијалогизована говорна разноликост“ (1989: 34), јер је дијалогичност „природна оријентација сваке живе речи“ (Исто). 
Алије Ђерзелеза“ Андрић дијалогизује текст, тј. широко познато епско предање о јунаку на које овај имплицира, сучељавајући, кроз пародијски поступак, позиције типичног епског, митског јунака и модерног субјекта какав је заправо његов Алија Ђерзелез. Широко распрострањено епско певање о јунацима потиче од митске представе о јунаштву као врсти посебне делатности, у коју се ступа посвећењем, иницијацијом у јунака, а она се постиже одвајањем од женског начела и одбијањем да се учествује у циклусу плођења, рађања и умирања, као и победом над хтонским бићем, најчешће змијом. Тако се јунак издваја из заједнице, али не да би постао индивидуа, већ да би служио заједници тако што је штити, побеђује зло којој јој прети и брани слабије. Он је стопљен са природом, виле, пећине и планине су његово окружење, стално је на путу и на мегданима, а он, његов коњ и оружје чине целину. Такав јунак је и Алија Ђерзелез:

Међу посљедњима је стигао Ђерзелез. Пјесма је ишла пред њим. На бијелу коњу крвавих очију, он је јахао раванлуком, црвене су ките биле бијелца по очима, а дуги, чистим златом везени чевкени на Ђерзелезу сјали су и поигравали на вјетру. (Андрић 1981: 10)

Тако на самом почетку приповетке сажима епску историју свог јунака аутор, да би већ у следећем пасусу пародијским поступком сучелио почетну слику са потпуно другачијом:

Кад сјаха и пође према капији, видјело се да је необично низак и здепаст и да хода споро и раскорачено као људи који нису навикли да ходе пјешице. Руке су му биле несразмјерно дуге. Назва набусито и нејасно мерхаба и уђе у кахву. Сад кад је сишао с коња, као с неког пиједестала, поче да се губи страх и респект и, 
као да се изједначио с осталима, почеше му прилазити и започињати разговор. (Исто)

Оваквим поступком, Андрић постепено демитологизује јунака, али не да би негирао његову почетну митску позицију, већ кроз пародирање постигнуто дијалогизацијом са позицијом модерног човека, даје слику модерног света у коме се човек одвојио из заједнице, али не кроз посвећење и да би јој служио, као митски јунак, већ као издвојена индивидуа која се и дословно гега попут Алије када сиђе са коња, тј. када престаје да буде епски јунак, целина. Он тако постаје савремени човек, модерна индивидуа која се лелуја између сећања на своје митско порекло и суштину, и баналности трајања која ту слику неумитно разара и раствара. Сваки детаљ Андрићеве приповетке приказује и чак антиципира егзистенцију савременог човека: приземљење, улазак у цивилизацију, потрагу за лепотом и смислом, неизвесно лутање за нечим што му болно недостаје, а жена је у овом случају симбол те потраге, никако њен извор и исход.

Почетна митска слика и утврђена представа типичног епског јунака какав је Ђерзелез, остаје присутна у свести читалаца, али она је сучељена са индивидуализованим ликом модерног субјекта. Андрић даје само назнаке митске прошлости епског јунака и митске позадине дешавања (рачуна се на знање читаоца о типичном епском јунаку), и онда га дијалогизује и демитологизује, не самог Алију Ђерзелеза, него посредством слике архаичног јунака слика савремени свет који се историзовао, утонуо у атмосферу апокалипсе и демитологизовао. ${ }^{3}$

3 О граници између митског и не-митског пише и Миодраг Павловић, српки песник и есејиста, у есејима „Шта је мит?““ и „Иронија у миту“, истичући да од почетне митске ситуације настаје језик и човеков говор о миту и почетак језичких умет- 
Кроз „Пут Алије Ђерзелеза“ се паралелно одиграва и контраиницијација митског јунака, баш у додиру са свакодневним, интимним и друштвеним аспектима живота - граду, хану, јавној кући, светковинама, просторима који су резулатат људске цивилизације, изласка из природе, ограђивања сопственог простора отргнутог од ње. Јунак је у својој почетној изворној позицији стопљен са природом, пећинама, шумама, а у граду, у мноштву, у празницима и окупљањима, он се приземљује и улази у свакодневицу, у баналност људског трајања. Он силази са коња и његова фигура постаје гротескна, почиње да се дружи са људима и они га своде на своју меру и испод ње, тражи лепоту и она га рањава и измиче му:

За неколико дана посве је ишчезао чаробни круг око Ђерзелеза; један по један, приближавали су му се ови бјелосвјетски људи с несвјесном жељом да се с њим изједначе, или да га подреде себи. (Андрић 1981: 11)

Још једна битна одлика модерне књижевности, њена карневализација, коју Бахтин одређује као по-

ничких дела. Он објашњава исконску људску потребу за митом који „отвара“ нешто око и иза људског видика, а то је препрека или „опна“ између два света, људског и божанског. (Павловић 1984: 131). Насупрот митско-химничном оптимизму стоји трагедија, „која почиње кад се мит руши“, а сама трагедија представља „распадање и расап мита“. Корен трагичности је у губитку „митског смисла“, попут западног хришћанства које је „истицањем распећа постало трагично, а није остало митско“, а трагичност је „увод у рационализам“ (Исто, 133). Овде Павловић супротставља и историју и мит, и јасно одређује границу између историје и мита: „Трагедија је излазак из мита, улазак у искуство, емпирију. Историја је, рецимо, искуство трајања. Мит је оно што постоји без искуства пре њега. И поезија има примордијалност мита, она је усхит мимо историје“ (Исто). 
ступак који подразумева амбивалентност и недовршеност, тј. промену и развој у првом реду и која нужно укључује и гротеску, произилази из карневалске, традиционалне културе, када су светковине и празници били везани за цикличност промена у свету и природи и значили су привремени раскид са устаљеним друштвеним нормама. У савременој књижевности 20. века процес карневализације и гротескна визија улазе у књижевност и уметност, као поступак и могућност сагледавања и сликања несавршеног, недовршеног и хаотичног света. Бахтин је такву књижевност називао гротескни реализам 20. века, али је важно истаћи да у свим таквим делима напоредо постоји и функционише класични естетски канон. И Андрићев Ђерзелез симболизује амбивалентност и недовршеност, монолитне одлике епског јунака се растварају и смењују са гротескним сликама и обличјем. На моменте, Алија Ђерзелез постаје контраслика оног митског јунака чија слава иде испред њега:

Распасао се па му спадају и борају се чакшире, а ионако кратке ноге му изгледају још краће и још дебље; отпасао му се појас од ибришима вишњеве боје па се вуче за њим, поливен ракијом и умрљан пепелом. Једва се држи на ногама, кривуда и смјера час лијево, час десно. (Андрић, 1981: 21)

Гротеском се бавио и немачки теоретичар Волфганг Кајзер у делу Гройескно у сликарстиву и йеснишииву, наводећи да улазак у померен, гротескни свет у прози прве половине 20. века више и не постоји, зато што је свет већ дат као стран и отуђен: „Ми смо од ренесансне орнаментике надаље пратили непрестан процес распадања: (...) губитак идентитета, изобличавање 'природних' пропорција и сл. А онда смо се суочили са 
новим видовима растакања: са укидањем категорија предмета, са разарањем појма личности, са разбијањем историјског реда и устројства“ (Кајзер, 2004: 259).

У таквом гротескном свету, Алијин оријентални костим и егзотичност простора кроз који пролази, постају само кулисе које се могу мењати и које показују суштинску огољеност и беспомоћност савременог субјекта у свету који је изгубио смисао за исконску митску светлост. У таквом свету не може постојати ни истински сусрет мушког и женског начела, лепота је недостижна и све даља, а некадашњи јунак прихвата пораз и узима од празног живота једино што може да пружи - контраслику љубави и лепоте, до које се може доћи не јунаштвом, не подвигом, не изузетношћу, него на главној позорници савременог света - тржишту. Тржиште и закони куповине и продаје одређују све односе и човек се безуспешно батрга у покушајима да изађе из тог круга и досегне светлост. У сваком савременом субјекту постоји митска основа, она жица која забруји када човек дође у истински додир са митским, везом са свеукупним светом и енергијама стварања. То буди чежњу за оживљавањем митског у свакодневици и унутрашњи свет се колеба између митске представе о свемоћи, снази и победи добра над злом, и фрагментизованом, обесмишљеном свакодневицом, где се живот сматра релизованим ако успева да прибави човеку више робе. Зато патња савременог човека и приземљеног митског јунака који поприма гротескно обличје Ђерзелеза Алије, није трагична и нема размер античке трагедије: позиција савременог човека је трагикомична и гротескна. У њој нема узвишености, само бледих одсјаја исконског живота кога се сви сећају у својој најдубљој суштини, али неспретно и најчешће неуспешно покушавају да га досегну. 
Смех, разузданост, исмевање, који прате Алију дешавају се у време светковања Ђурђевдана и Рамазана, у доба карневалског светковања када се сва правила крше, а идентитет се преображава и губи до непрепознатљивости.

Био је Рамазан и дању је све мировало, али ноћу се град проламао од свирке, сијела и ашиковања по махалама. Дућани, пуни воћа, и кахве, пуни људи, били су по сву ноћ отворени. (Андрић 1981: 25)

Поступак карневализације $\mathrm{e}^{4}$ за којим посеже аутор, кроз експлицитно присуство карневала, тј. празника као хронотопа ${ }^{5}$, остварује се принцип привремено измењеног поретка живота који нуди могућност испољавања промењеног идентитета. Промењени идентитет савременог човека огледа се тако кроз однос са некадашњим

4 Ослањајући се на Бахтинову теорију карневализације, пародије и гротеске, у Андрићевој приповеци „Пут Алије Ђерзелеза“ можемо уочити одређене елементе које Бахтин истиче као типичне одлике карневализовања модерне књижевности, попут пародије, смеха, ироније, гротеске, преображаја, дијалога, те експлицитног или имплицитног присуства карневала, тј. у овом случају празника као хронотопа којим се привремено мења поредак живота и који ствара могућности испољавања промењеног идентитета.

5 У студији Облици времена и хронойойа у роману, Бахтин успоставља и дефинише појам хронойой $a$ ) као „суштинску узајамну везу временских и просторних односа, уметнички освојених у књижевности. [...] У књижевно-уметничком хронотопу скривена су просторна и временска обележја у смишљену и конкретну целину. Време се овде згушњава, стеже, постаје уметнички видљиво; простор се напиње, увлачи се у кретање времена, сижеа, историје. Обележја времена разоткривају се у простору, а простор се осмишљава и мери временом. Уметнички хронотоп одликује се тим пресецањем низова и сливањем обележја. [...] Хронотоп као формално-садржајна категорија одређује (у знатној мери) и лик човека у књижевности; тај лик је увек суштински хронотопичан (Бахтин 1989: 193-194). 
утврђеним поретком света - људска заједница и сваки њен члан дубоко у себи има исконску потребу да искорачи из приватног живота, али данас је то могуће само посредно. Посматрано из овог угла, постаје јасније зашто се масовно славе спортски „подвизи“ и организују праве мале паганске светковине поводом победа спортских јунака, који се славе и кују у звезде, па бацају у блато и прашину када сиђу са висине јунаштва и приближе се људима који свој нагон за јуначким постојањем живе кроз њих. Андрић прецизно слика и антиципира овакву позицију модерног човека који хероје поштује само када су удаљени од њих и њихових баналних живота:

Нису му могли разабрати израз лица, али тај поглед је био опасан. У један час као да сви осјетише да су претјерали. Даљина и одстојање су му враћали све што је изгубио у друштву с њима. Сад кад је био три стотине корака далеко од њих и ваљао се према њима, мрк и тежак, као да их нагло освијести тај размак; и најбезбрижније међу њима испуни страх. (Андрић 1981: 14)

Ипак, идентификација заједнице једног језика са јунацима остаје снажна и вечна. Она је основа митске сублимације око које се заједница рађа, ствара и одржава, а укидање смисла за митско значи и смрт и одумирање заједнице. Зато Андрићев Ђерзелез није само пародија ради пародије, заправо он овде посеже за пародијским поступком и карневализацијом да би показао како се рушењем мита руши и заједница и како модерни човек постаје индивидуа дубоко усамљена у потрази за смислом изван себе. Атомизација човека се не зауставља тако одвајањем људи из заједнице у засебне индивидуе, већ се фрагментација и губитак осећаја целине и целовитости наставља унутар сваке индиви- 
дуе растакањем заједнице. Тако у савременом тренутку долази до низа виртуелних живота унутар саме личности, борбе исконских унутрашњих тежњи и нејасне слике света која више не личи на целину, већ се пре може описати као низ набацаних „фрејмова“б који се боре у свести појединца. Ратови и мегдани данашњице су дехуманизовани, некадашњи јунаци и мегданџије су ратни злочинци, савремени војник нема готово ништа заједничко са митским представама јунака бранилаца или освајача; он је софтверски добро уигран и роботизовано обучен да нанесе највећу штету противнику уз очување свог живота. Заокружење процеса контраиницијације јуначког начела може се јасно сагледати кроз феномен стварања тзв. суперхероја без митског супстрата, у савременој стрип-култури и филмовима. ${ }^{7} \mathrm{Cy-}$ перхерој не потиче из елемената или исконске природе, његова припадност заједници је нејасна, он је екумениста, значи ничији и свачији; не постоји идентификација заједнице са њим и његовим подвизима; супер-моћи не потичу од митског бића или необичним рођењем, већ од вештачких супстрата или далеких апстрактних галаксија; живи уклопљен у свакодневни приватни живот и по потреби се претвара у суперхероја. Тако се стварају вештачки митови без стварне кохезионе силе и додатно разарају осећај за целину савременог човека, заточеника великог тржишта.

Амбивалентна позиција модерног субјекта наглашена је недовршеном и несавршеном сликом света

6 Брзина смењивања слика или број слика по секунди (енгл. FPS - frames per second) мера је фреквентности промене слика на анимацијама, односно колико се слика приказује у секунди.

7 Сматра се да је први суперхерој популарни стрип-јунак Супермен, настао 1938, који је био и инспирација за назив којим се ови јунаци стрипова и касније филмова, називају. 
из које нестају традиционална упоришта и немогућност повратка на почетну позицију. После „Пута Алије Ђерзелеза“, нема повратка у изворну ситуацију епског јунака: „Несрећан, славан и смијешан, тако је обишао Ђерзелез по царевине. О његовим доживљајима тог љета зна се веома мало; и он сам их је одмах заборављао“ (Андрић, 1981: 24). Дакле, песма више не иде испред јунака...

Суштинска модерност Андрићевог приповедачког поступка која је уочена у приповеци „Пут Алије Ђерзелеза“, поставља је у доминантни ток модерне светске прозе, заједно са писцима 20. века који превасходно сликају свет у којем је тешко или немогуће наћи смер и сврху, који је изгубио смисао, у коме је апсурдност постала преовлађујући доживљај, и где страх од живота надвладава страх од смрти због померених односа у традиционалном поретку ствари. Оваква поремећена слика света остварује се кроз књижевна дела дијалогизацијом, пародирањем, смехом, гротеском и карневализовањем књижевности, онако како је ове појмове поставио Михаил Бахтин, а у сагласности са Кајзеровом оценом да је гротеска доминантни стилски поступак модерне књижевности, јер омогућава писцима да изразе поремећене и померене односе савременог доба. Андрићева приповедачки поступак у приповеци „Пут Алије Ђерзелеза“ наглашава такав основни однос према свету, управо путем стилског и изражајног средства пародирања, гротеске и карневализације.

И на крају, може се поново поставити питање зашто Андрић преображава епског јунака у модерног субјекта који лелуја између утврђеног света који се распада и новог за који не зна ни где почиње, ни куда иде, ни како се по њему хода? Приповетка се зове „Пут Алије Ђерзелеза“. Куда он путује? Где је почетак, а где 
крај тог пута? Андрићев јунак се не креће ка одређеном циљу, он не иде ка нечемy, он се креће og нечега, те је само кретање и пут његов једини смисао. Сваки истински циљ у свету поремећених односа између ствари је недостижан, и јунаку остају лажни пародирани циљеви попут суве јабуке према којој Алија трчи у дворишту хана, у нади да ће тако задобити Венецијанку, тај симбол недостижне жеље и лепоте. Јабуку он, наравно, достиже, али жену за којом жуди не, као што никада ни неће: „Гледајући тај прозор, затворен, хладан и загонетан, као женски поглед и људско срце, диже се у њему свом снагом већ заборављен гњев и јад“" (Андрић 1981: 15). У овом светлу, жена је симбол недостижног и неухватљивог, оног за чиме човек жуди у свету који не пружа никакво сигурно упориште ни оријентир, који подсећа на место хаотичних судара лелујавих индивидуа које се сударају и додирују у пролазу, без истинског додира и смисла. Космичка усамљеност човека постаје огољена када он иступа из заједнице, овог пута не својим избором, да би посвећењем прешао у јуначко деловање и на тај начин штитито заједницу и њене каноне постојања, већ у околностима модерног света, када је она потпуна и несавладива. Зато су сусрети могући само на тржишту, том новом божанству савременог света. Отуда Андрић пародирањем измешта митског јунака у позицију модерног субјекта, показујући како се остаци сећања на везу са митским доживљајем света растачу неумитно у свету који прошлост гледа као издвојени сегмент сећања, без стварне везе са садашњицом. Без истинског додира са прошлошћу, или у елитовском смислу речено са живом традицијом, ${ }^{8}$ човек је осуђен на вечно лутање за смис-

8 „Традиција је ствар која има много шири значај. Она се не може наследити, а ако вам је потребна морате је стећи великим трудом. Она на првом месту обухвата осећање историје за које, 
лом, али без некадашњег трагичног патоса и катарзе који су осмишљавали ту потрагу, макар и безуспешну. Он је овај пут трагикомична и гротескна фигура која се неспретно и несрећно, попут Андрићевог Алије Ђерзелеза, гега у свету баналности, покушавајући, безуспешно, да пронађе смисао и сврху тог кретања. Зато је Андрићев Ђерзелез и наш савременик: некадашњи митски јунак са живим сећањем на сврху вишег реда и садашњи усамљени субјекат који у несавршеном и неодређеном свету неуморно трага за њом, осуђен да је не досегне, али где сада сама потрага, тај вечни пут, постају та недостижна, али једина могућа виша сврха и смисао: „Силом је склапао очи. Хтио је да продужи тај час без мисли и жеље, да што боље отпочине, као човјек ком је дан само кратак одмор и коме ваља даље путовати“ (Андрић, 1981: 32).

\section{Извори и литература}

Андрић, Иво. Знакови у Сабрана gела Иве Андрића. Београд: Просвета, 1981. Штампано.

Бахтин, Михаил. Проблеми йоейике Досйојевской, прев. Милица Николић, Београд: Нолит, 1967. Штампано.

Бахтин, Михаил. Франсоа Рабле и нарояна култиура среgюет века, Београд: Нолит, 1978. Штампано.

Бахтин, Михаил. О роману, прев. Александар Бадњаревић. Београд: Нолит, 1989. Штампано.

безмало, можемо рећи да је неопходно сваком оном ко би хтео да буде песник и после своје двадесет пете године; а то осећање историје обухвата запажање не само онога што је прошло у прошлости, већ и што је садашње у прошлости; осећање историје присиљава човека да не пише прожет до сржи само својом генерацијом, већ са осећањем да читава европска литература почев од Хомера, и у оквиру ње читава литература његове сопствене земље, истовремено егзистирају и истовремено сачињавају један поредак.“ (Елиот 1963: 35) 
Елиот, Т.С. Изабрани йексӣови. Београд: Просвета, 1963. Штампано.

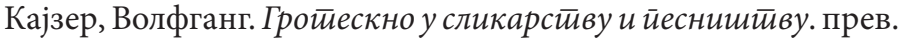
Томислав Бекић. Нови Сад: Светови, 2004. Штамапно.

Микић, Радивоје. Посӣуйак карневализаиије. Београд: Филип Вишњић, 1988. Штампано.

Павловић, Миодраг. Прирояни облик и лик. Београд: Нолит, 1984. Штампано.

Maja Radonić

\section{ALIJA ĐERZELEZ - OUR CONTEMPORARY}

\section{Summary}

In one of his most significant narratives „Put Alije Đerzeleza“, Ivo Andrić, through demitologization and parody procedure, is reactivated the character of a typical hero of epic poems, creating a modern hero, a man separated from the community, lonely and divided by internal conflicts and fears.. Despite the archaic and eastern ambiance and the mythical basis of the story of a great hero, Andrićs Đerzelez has become a symbol of a modern man who has crossed the path from heroic times to the tragicomedy of modernity. The work points to irony and parody as the basic narrative process by which the author destroyed the original mythical basis of the story, in order to re-formulate it, creating a picture of the anxious existence of a modern subject, a man moving between a mythical notion of his omnipotence and reality that consistently destroys that image.

Key words: Ivo Andrić, «Put Alije Đerzeleza», parody, myth, reactualization 